\title{
Effect of Alkaline Metal Catalyst to Transesterification of Jatropha Curcas Oil
}

\author{
DiniKurniawatia \\ a JurusanTeknikMesin, FakultasTeknik, UniversitasMuhammadiyah Malang \\ Jl. Raya Tlogomas No. 246 Malang 65144 \\ Telp. (0341) 464318-128 Fax. (0341) 460782 \\ e-mail:dini@umm.ac.id,
}

\begin{abstract}
Biodiesel is a renewable energy made from oil or fat. It is either vegetable or animal oil or fat. By using catalyst, both substances are processed by triglyceride to modify it to methyl esters. This research concerned was to find out the potency of alkaline metal (IIA) catalyst in processing biodiesel. This process was initiated by testing oil free fatty acid to determine processing method. FFA value is very important in the beginning of process as it correlates to further reaction process. Temperature variation was set on $30^{\circ}$ to $70^{\circ}$ for 6 hours reaction. Result shows that the best methyl esters value was obtained by using $\mathrm{Mg}(\mathrm{OH})_{2}, \mathrm{Ca}(\mathrm{OH})_{2}$ and $\mathrm{Ba}(\mathrm{OH})_{2}$ catalysts, respectively in $61,75 \%$; $62,66 \%$ and $73,03 \%$ on $60^{\circ} \mathrm{C}$ reaction temperature.
\end{abstract}

Keywords: Oil; Jatropha Curcas; Biodiesel; Transesterification; Kinematic Viscosity

\section{INTRODUCTION}

As an alternative renewable energy, biodiesel is obtained from esterification and transesterification reaction of oil and fat. The reaction transform triglyceride to methyl esters. Furthermore, the transformation result i.e. methyl esters, is widely recognized as biodiesel [1]. The raw material may use oil or fat from either vegetable or animal oil. The raw material for the process may use the pure oil or fat and also used oil or fat in producing biodiesel. For different raw material, there would be difference process on purifying oil.

Biodiesel is "green" fuel with free environmental problems comparing with diesel. It needs no engine modification for B20 mixture and for other than B20 mixture need slightly modification. Moreover, biodiesel would give better engine performance than diesel as it has high cetane value [2][3]. Pure biodiesel can be directly used on diesel engine without additional lubricants such as on diesel and more environmental friendly biodiesel [4][5].

Vegetable oil used in this research is Jatropha oil of Jatropha seed (Jatropha curcas L.). This kind of plant, Jatropha curcas L., can be used as biodiesel material because it does not compete with food needs. Its oil contents are higher than palm oil, with $32-35 \%$ of oil content in Jatropha compare with $24 \%$ in palm oil. Jatropha plant is easy to cultivate even its productivity is depending on variety, soil fertility and texture, soil height with high rainfall and drainage. The most important consideration is rainfall, drainage and height [6].

Process of producing biodiesel has several steps started by pre-treatment, esterification, transesterification, and purifying. In current conditions, producing biodiesel can be conducted with or without esterification and process would be consisted of pretreatment, transesterification, and purifying. In transesterification process, it can be conducted with or without catalyst. When the catalyst is not used, the process is able to be proceed in higher temperature above alcohol temperature. This method is called supercritical. On transesterification using catalyst as conducted by Kulkarni and Dalai (2006)[7], sodium hydroxide ( $\mathrm{NaOH})$, potassium hydroxide $(\mathrm{KOH})$, and Sodium methoxide $\left(\mathrm{CH}_{3} \mathrm{ONa}\right)$ are commonly used. Quality of methyl esters is determined by additive substance. The mostly used additive is metals such as $\mathrm{Mn}$ and $\mathrm{Ni}$ [8], $\mathrm{Mg}$ and $\mathrm{Mo}$ [9], oxide metals and halogen, such as $\mathrm{CuO}, \mathrm{FeCl}_{3}[10]$. These substances have advantage to 
decrease exhaust gas emission of methyl esters and is able to increase physical characteristic of methyl esters.

In this research, process of producing biodiesel of Jatropha oil is conducted with transesterification using $\mathrm{Mg}(\mathrm{OH})_{2}, \mathrm{Ca}(\mathrm{OH})_{2}$ and $\mathrm{Ba}(\mathrm{OH})_{2}$ catalysts in varied reaction temperature. The effect of variation on reaction temperature and catalyst used in transesterification process were the focus in this research.

\section{Method}

\subsection{Instrument and material}

Material used in this research is Jatropha curcas L. oil from Department of Agriculture, UMM. Pre-treatment process used pure phosphate acid to eliminate gum in oil. The transesterification process used $99,9 \%$ pure methanol and alkaline catalyst of alkaline metals, $\mathrm{Mg}(\mathrm{OH})_{2}, \mathrm{Ca}(\mathrm{OH})_{2}$ and $\mathrm{Ba}(\mathrm{OH})_{2}$. Catalyst weight used is varied to Jatropha oil weight.

Meanwhile, instruments used in research were reflux process and a set of washing and testing tools.

\subsection{Method}

Purifying of Jatropha oil conducted with degumming method to separate gum and dirt contained in raw Jatropha oil by using phosphate acid. The pure oil will be used for transesterification process. Initial tests to oil conducted to determine further process steps. FFA (Free Fatty Acid) on oil examined before determining the need on esterification and transesterification process, either one of it or both.

Furthermore, process on producing methyl esters is conducted by transesterification reaction method for 6 hours by molar ratio of methanol and oil of $6: 1$. Catalyst weight is varied in $1-8 \%$ to oil weight and $30-70^{\circ} \mathrm{C}$ reaction temperature. Moreover, product of reaction is separated by using separation funnel to divide methyl esters and glycerin. Methyl esters were washed with warm water and the water was separated after the washing process.

\subsection{Testing}

\subsubsection{Pre - treatment}

In pre-treatment, eliminating gum from oil conducted by using $1 \%$ phosphate acid in $90^{\circ} \mathrm{C}$ temperature in degumming process. Free fatty acid (FFA) content examined before determining further step.

\subsubsection{Esterification or transesterification}

Further process conducted after finding FFA content. Esterification process used acid catalyst while transesterification process used base catalyst. Transesterification process was conducted for 6 hours based on predetermined temperature. Result of this reaction was tested in physical and chemistry characteristics of methyl esters.

\subsubsection{Testing performance of diesel engine}

In this step, the best methyl esters from previous process was tested on diesel engine to know combustion performance for the use of methyl ester as fuel. Examination was conducted by mixing methyl ester with commercial fuel, diesel fuel.

\section{Result ANd Discussion}

\subsection{The effect of Free Fatty Acid (FFA) content}

FFA content on biodiesel or methyl esters production has great role as FFA determines further process of producing biodiesel. Oil converted to biodiesel has at least low FFA. Suggested FFA is less than $1-3 \%$ [11][12]. Van Gerpen (2004) also stated that low FFA lead to simpler biodiesel production by eliminating esterification process. Therefore, process chain is shorter and oil could be transesterified [11]. Oil for biodiesel material tested and results $0,1-0,5 \%$ FFA content that esterification process is no longer needed. 


\subsection{The effect of reaction temperature on biodiesel density}

Density is important parameter in observing diesel engine performance [13] because density variation would influence the power and characteristic of fuel burst during fuel injection process and combustion in combustion chamber [14]. Tat and Van Gerpen (2000) has indicated that biodiesel density depends on variation of reaction temperature [13]. As it is depicted in Graphic 3.1a, b, and c.

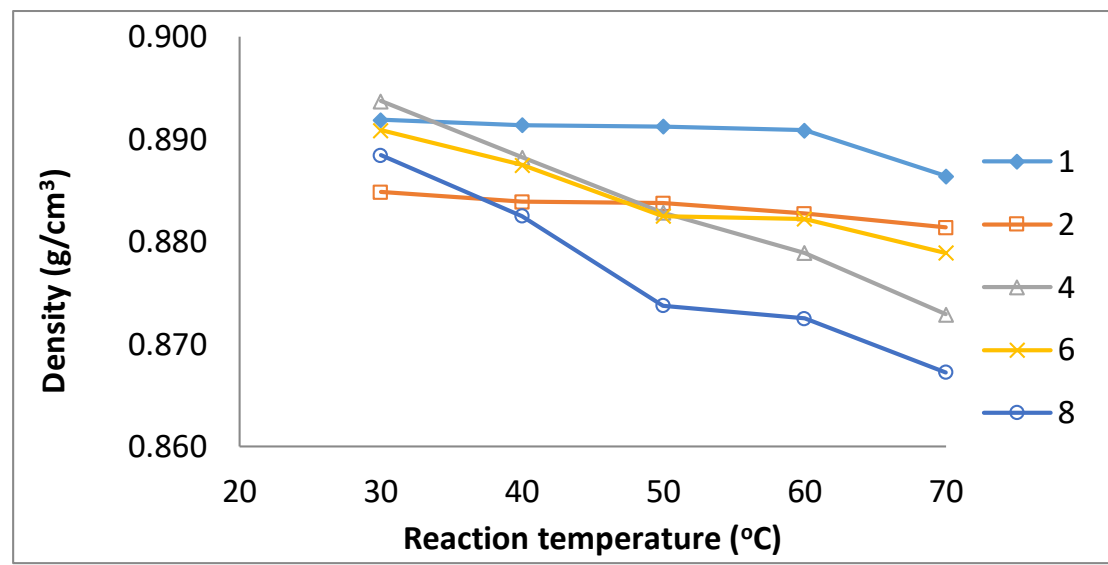

(a)

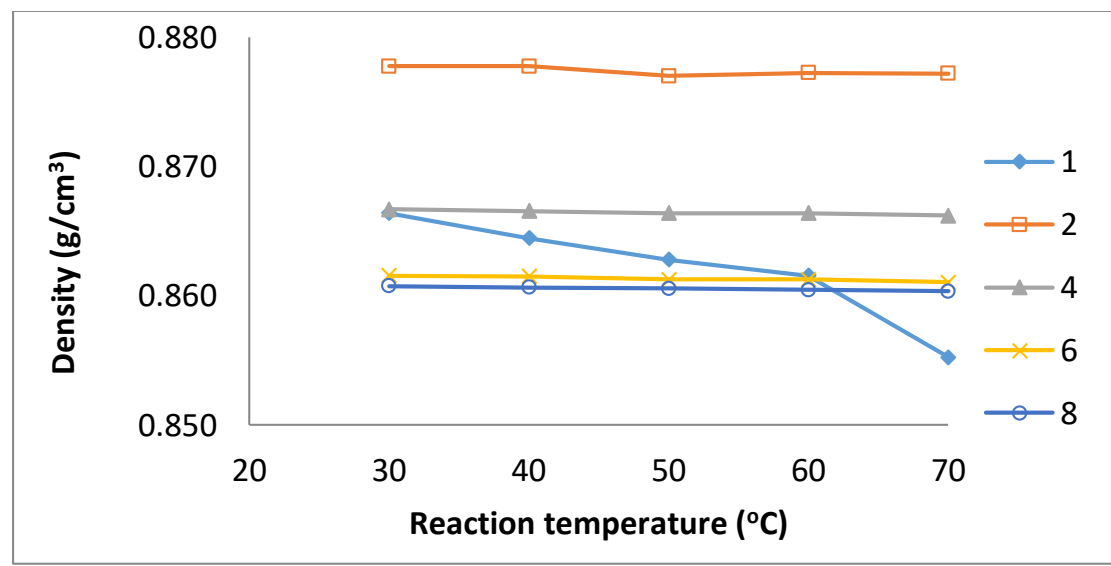

(b)

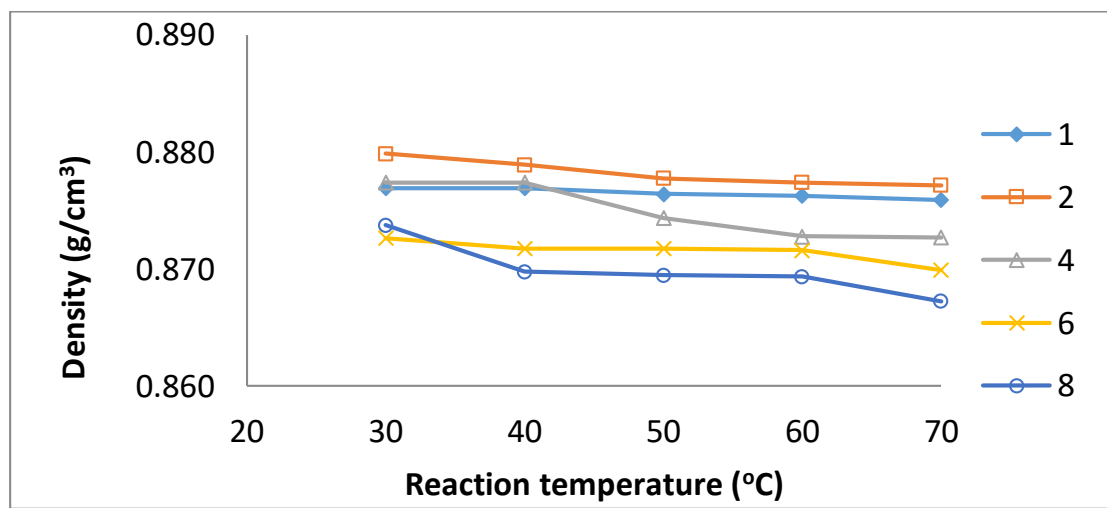

(c)

Graphic 3.1 The effect of reaction temperature toward density for catalyst weight (\%):

a. $\mathrm{Mg}(\mathrm{OH})_{2}$, b. $\mathrm{Ca}(\mathrm{OH})_{2}$, and c. $\mathrm{Ba}(\mathrm{OH})_{2}$ 
Graphic $3.1 \mathrm{a}, \mathrm{b}$ and $\mathrm{c}$ shows that methyl esters density decreases with the increasing temperature. Yet, the decrement of density value is less significant to diesel engine performance test and it is not the main determinant of biodiesel quality.

Methyl esters density obtained from gravimetric process by using pycnometer. The measurement gave results of density in range of $840-860 \mathrm{~kg} / \mathrm{m}^{3}$. It complies with SNI 04$7182-2006$ for biodiesel density range of $850-890 \mathrm{~kg} / \mathrm{m}^{3}$.

\subsection{The effect of reaction temperature to kinematic viscosity}

Process of transesterification reaction is conducted in temperature ranged from room temperature (the lowest temperature) to $650^{\circ} \mathrm{C}$ (the highest temperature) [12]. As methanol boiling point is $64,7^{\circ} \mathrm{C}$, transesterification reaction process above the temperature can cause methanol burnt. Ramadhas et al., (2005) stated that high temperature leads to saponification that needs to be avoided [15]. On Graphic 3.2 a, b, and c the effect of reaction temperature on kinematic viscosity is depicted.

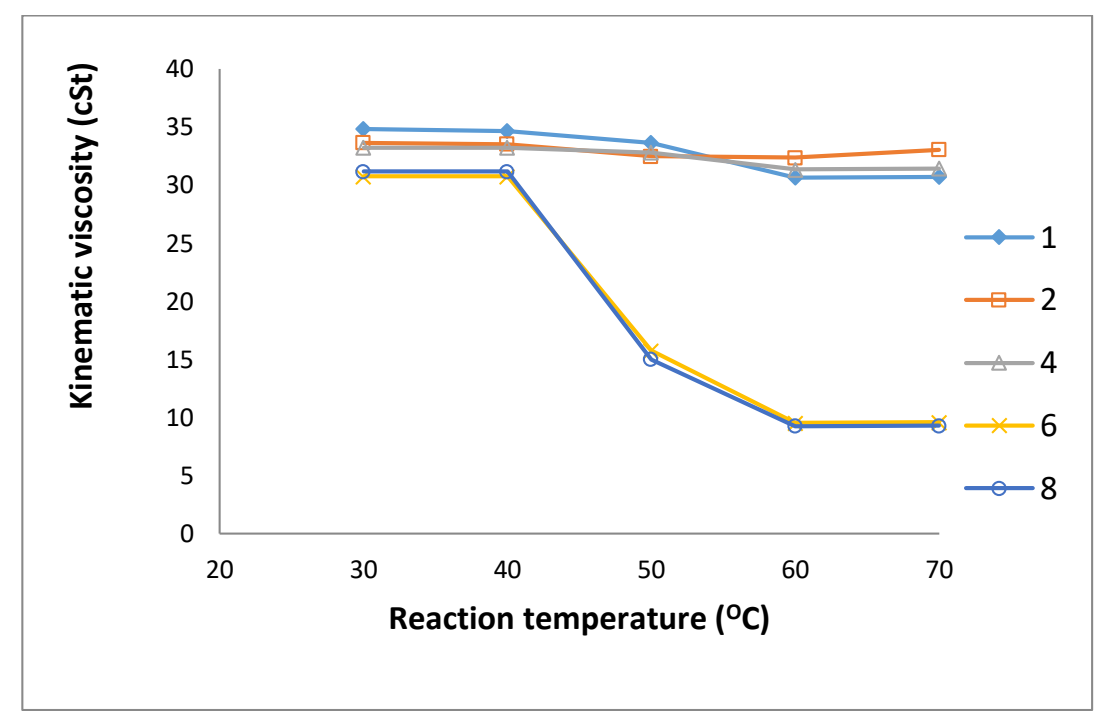

(a)

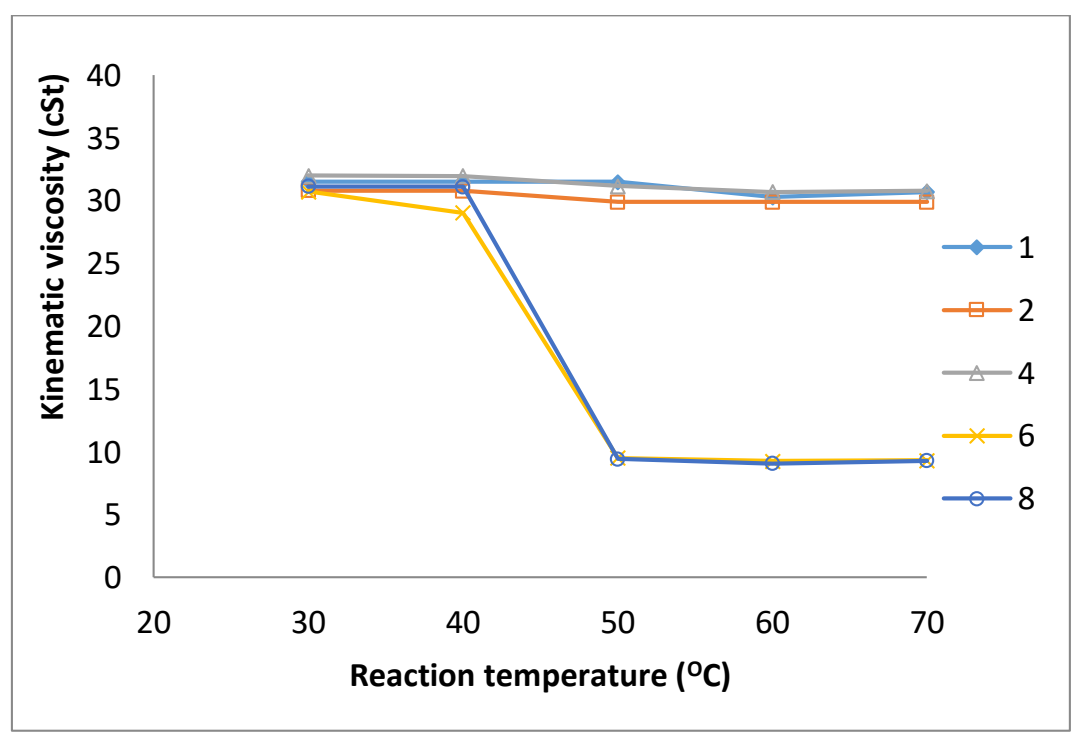

(b)

Graphic 3.2The effect of reaction temperature to kinematic viscosity for catalyst weight (\%): a. $\mathrm{Mg}(\mathrm{OH})_{2}$, b. $\mathrm{Ca}(\mathrm{OH})_{2}$, and c. $\mathrm{Ba}(\mathrm{OH})_{2}$ 


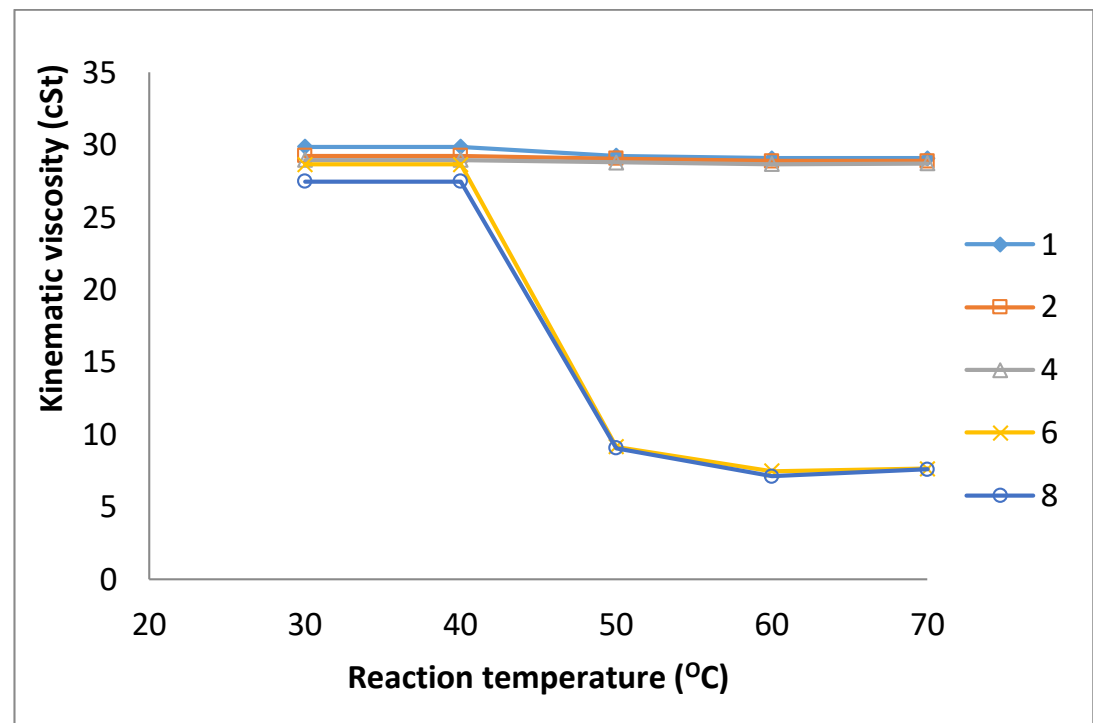

(c)

Graphic 3.2The effect of reaction temperature to kinematic viscosity for catalyst weight (\%): a. $\mathrm{Mg}(\mathrm{OH})_{2}$, b. $\mathrm{Ca}(\mathrm{OH})_{2}$, and c. $\mathrm{Ba}(\mathrm{OH})_{2}$ (continued)

Graphic $3.2 \mathrm{a}, \mathrm{b}$ and c shows the effect of reaction temperature to kinematic viscosity. The higher reaction temperature, the smaller or lower kinematic viscosity obtained. The best kinematic viscosity obtained in this study is in $60^{\circ} \mathrm{C}$ and catalyst weight of $8 \%$. These values were obtained from three catalysts, $\mathrm{Mg}(\mathrm{OH})_{2}, \mathrm{Ca}(\mathrm{OH})_{2}$ and $\mathrm{Ba}(\mathrm{OH})_{2}$, which respectively is $9,2737 \mathrm{cSt}, 9,0758 \mathrm{cSt}$ and 7,1059 cSt. It indicates that oil was converted to methyl esters in small fraction.

Kinematic viscosity was obtained by measurement with Ostwald viscometer. Kinematic viscosity is temperature function and it is measured on $40^{\circ} \mathrm{C}$ [16]. Its range corresponds to SNI 04-7182-2006, 2,3-6 mm²/s. Obtained viscosity of this research is $9,2737 \mathrm{cSt}$ for $8 \% \mathrm{Mg}(\mathrm{OH})_{2}$ in $60^{\circ} \mathrm{C}$. The value of $9,0758 \mathrm{cSt}$ viscosity is for $8 \% \mathrm{Ca}(\mathrm{OH})_{2}$ in $60^{\circ} \mathrm{C}$, while $7,1059 \mathrm{cSt}$ viscosity is for $8 \% \mathrm{Ba}(\mathrm{OH})_{2}$ in $60^{\circ} \mathrm{C}$. It indicates that oil converted to methyl esters with relatively small content.

\subsection{The effect of reaction temperature to Methyl esters percentage}

Determination of percentage for methyl esters content can be conducted in varius ways. The simplest approach is by measuring kinematic viscosity [17][18]. The approach is conducted based on the fact that pure biodiesel contains methyl esters. Therefore, it is only oil and methyl esters used as biodiesel material.

The higher reaction temperature, the lower kinematic viscosity of methyl esters that it indicates the more methyl esters converted. It is as depicted in Graphic $3.3 \mathrm{a}, \mathrm{b}$ and c.

Graphic 3.3a, b and c shows that methyl esters content increases with the increment of transesterification reaction temperature. It is due to the amount of methyl esters formed increases more and more. Yet, in $70^{\circ} \mathrm{C}$, methyl esters content is decreasing as transesterification reaction temperature above methanol boiling point. Reaction temperature above methanol boiling point is mostly avoided as it accelerates the occurrence of saponification reaction before alcoholic reaction [19]. 


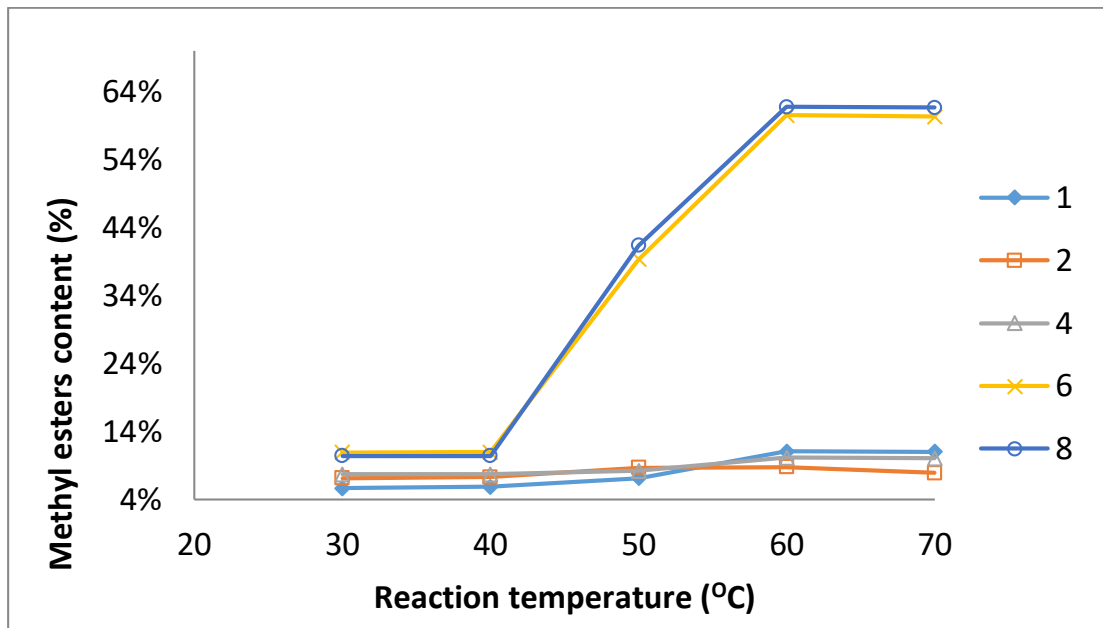

(a)

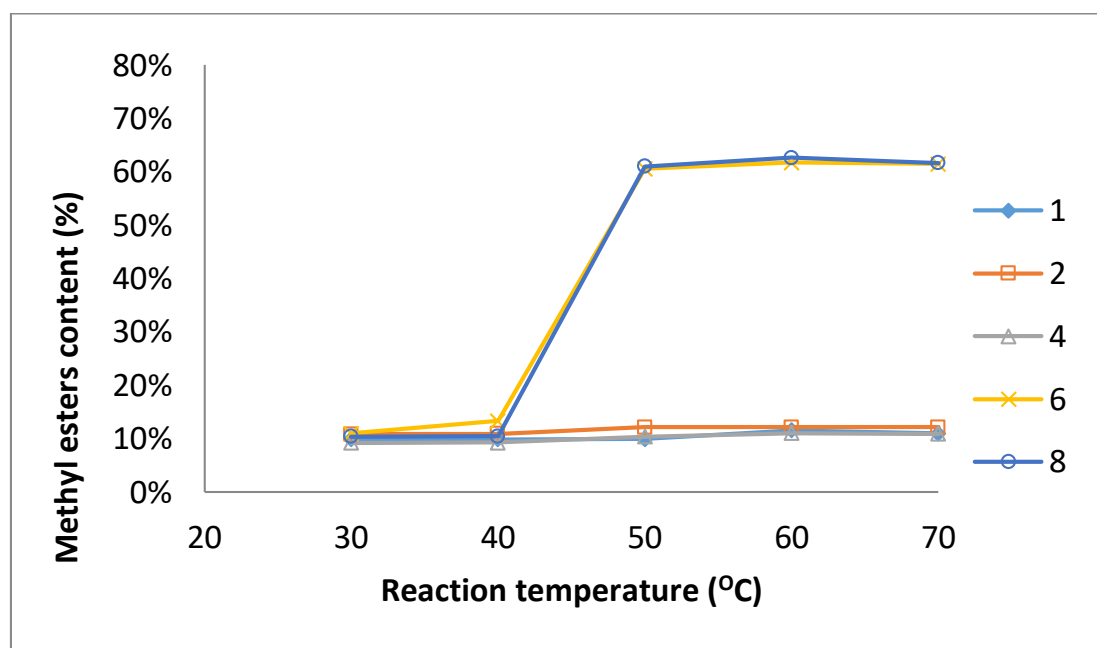

(b)

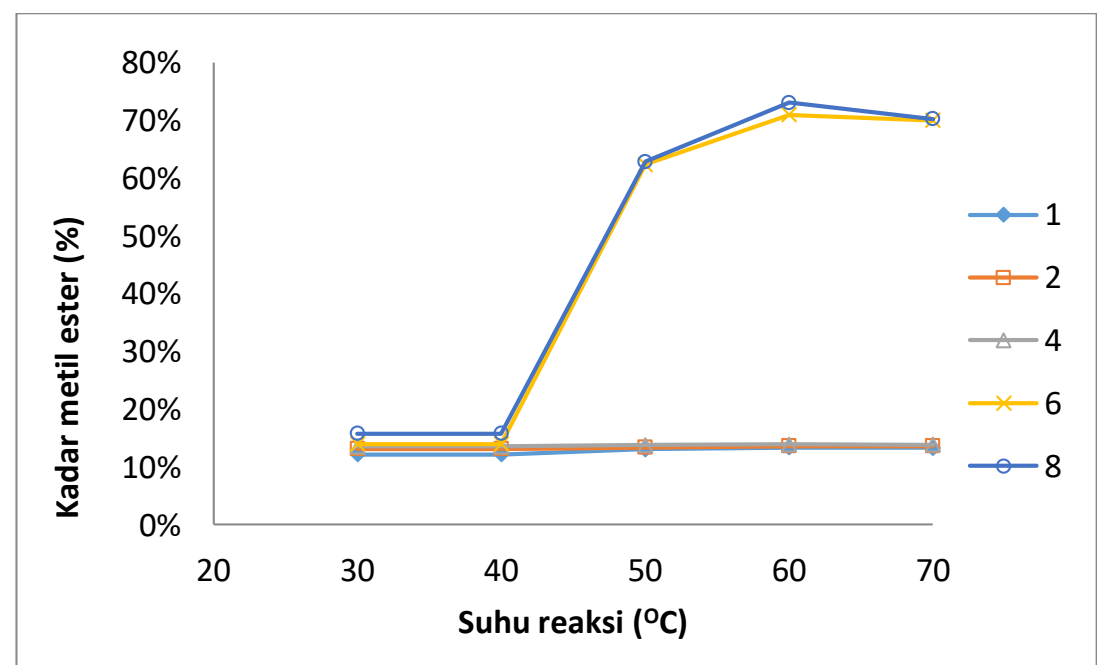

(c)

Graphic 3.3 The effect of reaction temperature to methyl esters content (\%) for catalyst weight (\%): a. $\mathrm{Mg}(\mathrm{OH})_{2}$, b. $\mathrm{Ca}(\mathrm{OH})_{2}$, and c. $\mathrm{Ba}(\mathrm{OH})_{2}$ 
The best methyl esters content obtained by this research used $\mathrm{Mg}(\mathrm{OH})_{2}, \mathrm{Ca}(\mathrm{OH})_{2}$ and $\mathrm{Ba}(\mathrm{OH})_{2}$ catalysts, respectively are $61,75 \% ; 62,66 \%$ and $73,03 \%$ on reaction temperature of $60^{\circ} \mathrm{C}$ with $8 \%$ catalyst $(\mathrm{w} / \mathrm{w})$.

\subsection{The effect of catalyst amount to methyl esters percentage (\%)}

The amount of catalyst is very important in transesterification process as catalyst converts Jatropha oil to methyl esters. The role of catalyst in transesterification process is to accelerate reaction, where catalyst decreases energy activation [20]. In this research, the role of catalyst treated by experiment on temperature variation and catalyst weight during 6 hours for each catalyst. It is as depicted in Graphic 3.4 a, b, and c.

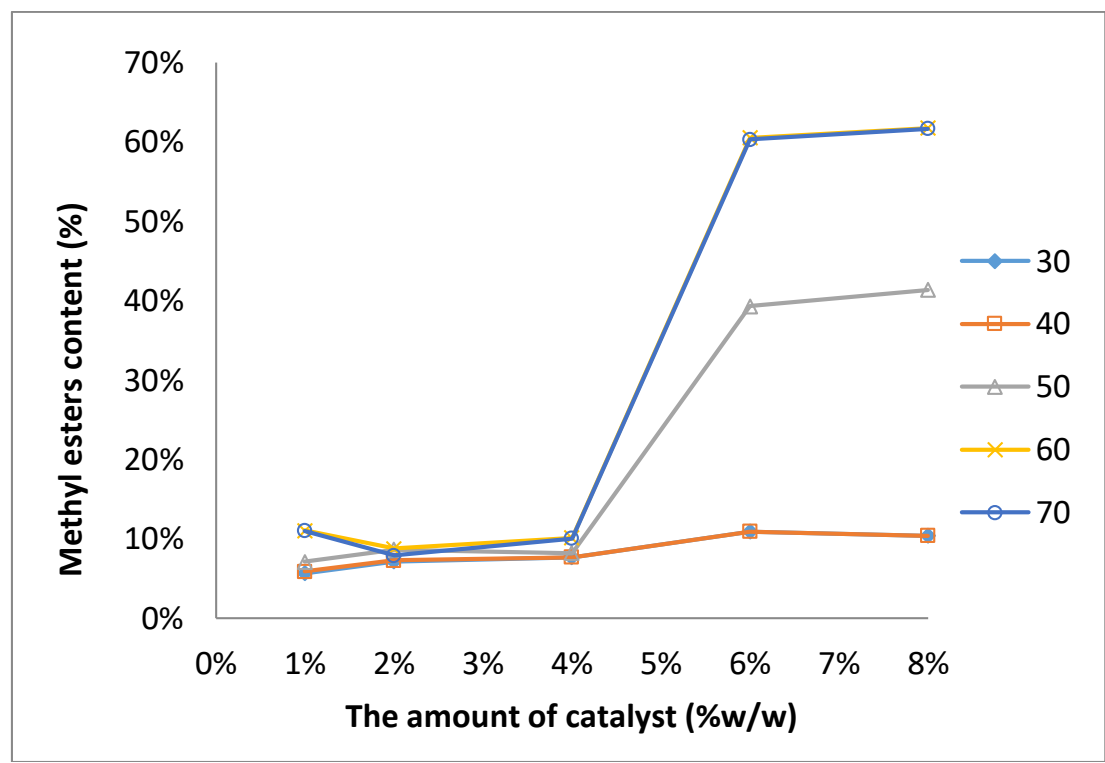

(a)

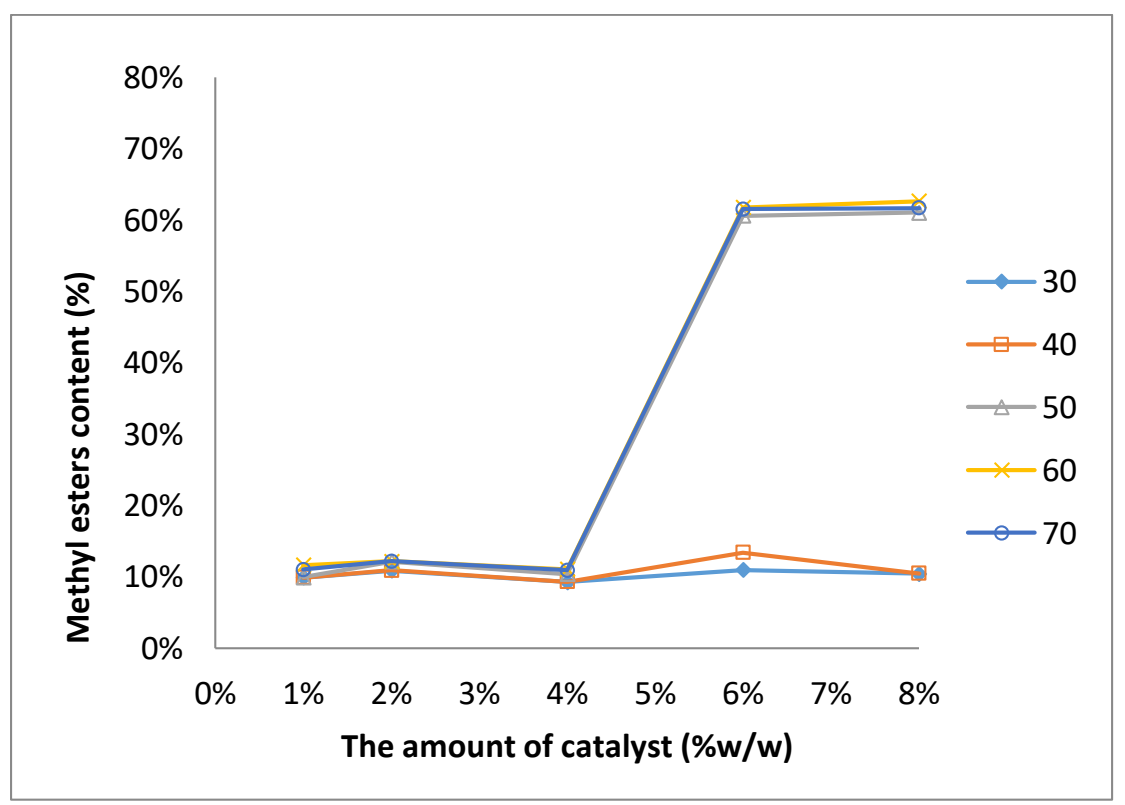

(b)

Graphi c3.4 The effect of catalyst amount (\%w/w) to methyl esters content for various reaction temperature of transesterification $\left({ }^{\circ} \mathrm{C}\right)$ with catalyst: a. $\mathrm{Mg}(\mathrm{OH})_{2}$, b. $\mathrm{Ca}(\mathrm{OH})_{2}$ and c. $\mathrm{Ba}(\mathrm{OH})_{2}$ 


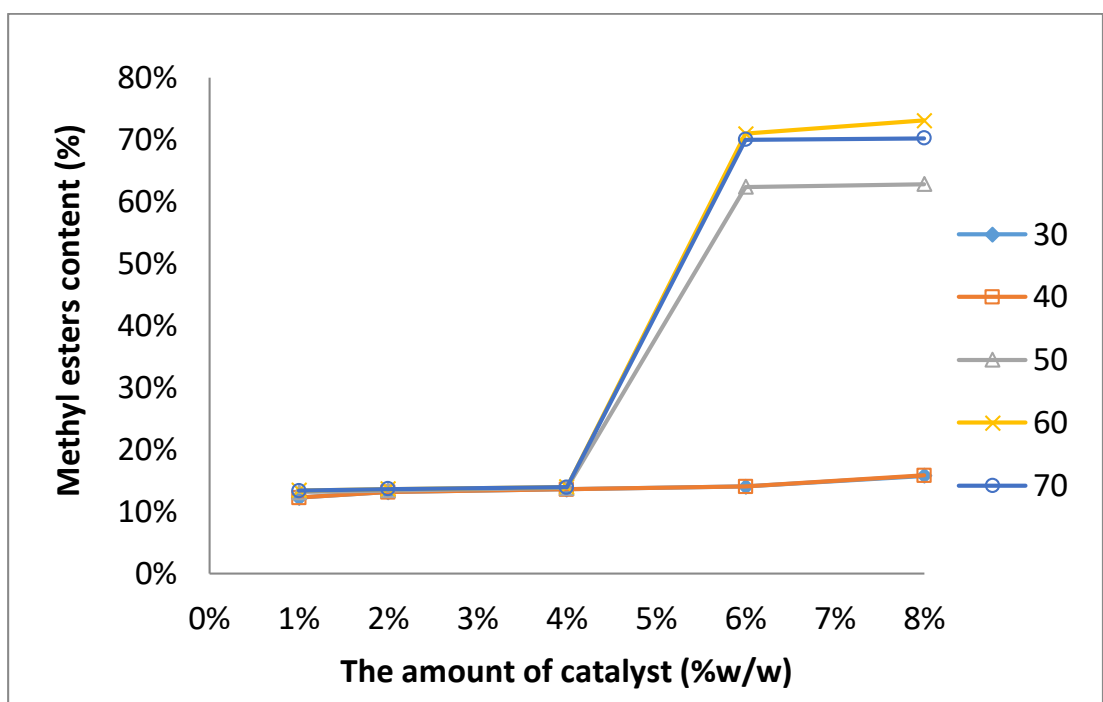

(c)

Graphic3.4 The effect of catalyst amount $(\% w / w)$ to methyl esters content for various reaction temperature of transesterification $\left({ }^{\circ} \mathrm{C}\right)$ with catalyst: a. $\mathrm{Mg}(\mathrm{OH})_{2}$, b. $\mathrm{Ca}(\mathrm{OH})_{2}$ and c. $\mathrm{Ba}(\mathrm{OH})_{2}$ (continued)

Graphic $3.4 a, b$ and $c$ shows that the role of catalyst by weight of $1 \%, 2 \%$ and $4 \%$ in reaction temperature of $30-70{ }^{\circ} \mathrm{C}$ has not given important role or in the current weight, they are not actively work yet to convert oil to methyl esters. It is shown by very small biodiesel content, for around $5,64 \%$ to $13,78 \%$. It is due to the transesterification reaction on heterogeneous catalyst needs more than $6 \%$ of catalyst amount [21].

The increment on the amount of catalyst would increase constants of reaction speed that will also accelerate reaction of forming product [20]. Yet, it does not mean a reaction should use the amount of catalyst in great number to increase methyl esters content as the more catalyst used will decreases methyl esters content. On the other word, the amount of catalyst used should be previously determined the optimum point of catalyst amount.

\subsection{The effect of molar ratio to transesterification reaction}

Stoichiometry ratio on transesterification reaction for methanol and oil is $3 \mathrm{~mol}$ of methanol and $1 \mathrm{~mol}$ of oil, where it will produce $3 \mathrm{~mol}$ of methyl esters and $1 \mathrm{~mol}$ of glycerol. The excess of alcohol is used during transesterification reaction process to ensure that oil is wholly converted to be methyl esters. Besides, it is also used to increase methyl esters conversion resulted and reaction will be in short term [22].

This research used oil molar ratio with methanol of $1: 6$ and is used heterogeneous catalyst. The magnitude of molar ratio and solid catalyst also influences oil conversion to biodiesel. The more amount of methanol added to catalyst will easily result methoxide substance.

\subsection{Examination on diesel machine performance}

Testing diesel engine was conducted on $1200 \mathrm{rpm}$ rotation and 1050 watt of machine load obtained from 3 heaters as the power. Biodiesel used is blending between diesel fuel and FAME in accordance with determined variation. Result of engine test is depicted in Graphic 3.5. 


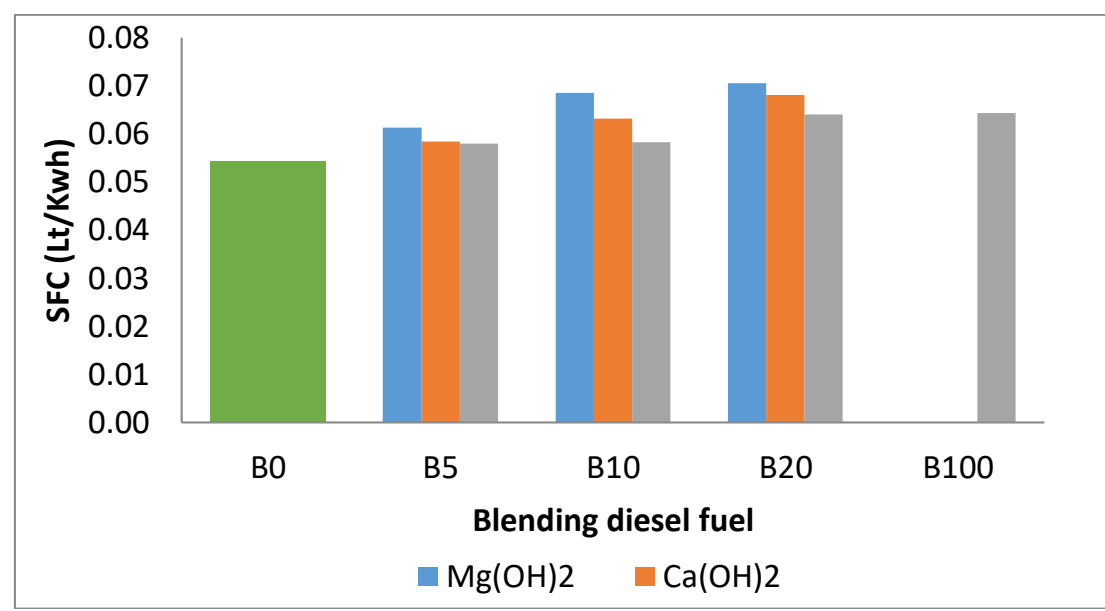

Graphic 3.5 The effect of biodiesel fuel Blending to fuel consumption (SFC)

Graphic 3.5 shows the correlation between the effects of diesel fuel blending with SFC. It shows that SFC is effectiveness indicator of pistons motor fuel in consuming fuel to produce power. Therefore, the smaller SFC the more efficient motor consuming fuel. Each catalyst increases with the increment of biodiesel amount added/blended with SFC. SFC of each catalyst increases from 0.0580 to 0.0706 if it compares with diesel fuel in only 0,0543 . It is influenced by several factors, heat value of biodiesel is more than diesel fuel and bigger biodiesel viscosity than diesel fuel.

The best diesel fuel Blending is B100, which is pure biodiesel without diesel fuel mixture. Using $\mathrm{Mg}(\mathrm{OH})_{2}$ and $\mathrm{Ca}(\mathrm{OH})_{2}$ catalysts, the blending cannot ignite diesel engine but for $\mathrm{Ba}(\mathrm{OH})_{2}$ catalyst when using $\mathrm{B} 100$ the engine was able to be ignited with more fuel when compared with other blending variation.

\subsection{The effect of power (Brake Horse Power) to the need of fuel (SFC)}

Motor power is motor work on driving axis. This scale is determined by rotation of diesel machine and torque resulted. BHP is also related to the need of fuel for resulting power. It is as depicted on Graphic 3.6.

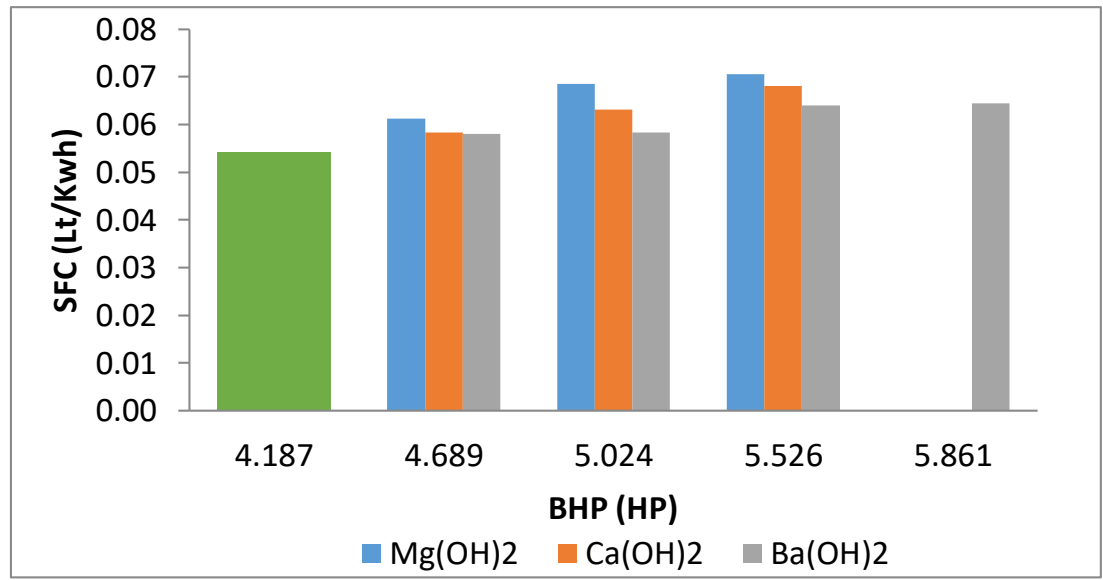

Graphic 3.6 The effect of BHP to SFC

Graphic 3.6 shows that the more power used for motor work the more fuel needed. The use of several catalysts also influences fuel consumption. The more increasing power, $\mathrm{Ba}(\mathrm{OH})_{2}$ catalyst tends to be more efficient than $\mathrm{Mg}(\mathrm{OH})_{2}$ and $\mathrm{Ca}(\mathrm{OH})_{2}$. It can be recognized by small SFC needed by using $\mathrm{Ba}(\mathrm{OH})_{2}$ catalyst, it is 0.0640 . Meanwhile, 
$\mathrm{Mg}(\mathrm{OH})_{2}$ and $\mathrm{Ca}(\mathrm{OH})_{2}$ catalysts is respectively 0,0706 and 0,0681 . Besides, the biggest power is $5,861, \mathrm{Mg}(\mathrm{OH})_{2}$ and $\mathrm{Ca}(\mathrm{OH})_{2}$ is unable to ignite the machine. It is due to both catalysts has higher viscosity than $\mathrm{Ba}(\mathrm{OH})_{2}$.

\subsection{The effect of diesel fuel blending to exhaust gas emission}

Engine test was conducted to find out engine performance and emission content from combusting fuel. Emissions observed are $\mathrm{CO}$ and $\mathrm{CO}_{2}$. Besides, it can be observed $\mathrm{O}_{2}$ resulted. It is as depicted in Graphic 3.7 and 3.8.

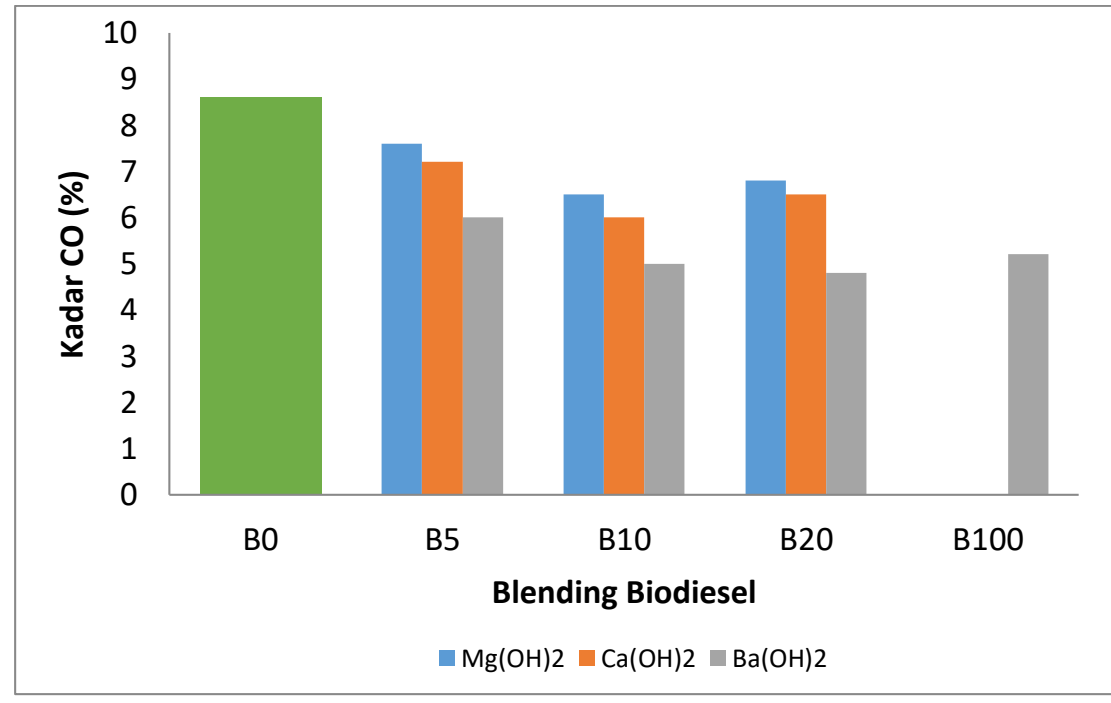

Graphic 3.7 The effect of diesel fuel blending to CO content

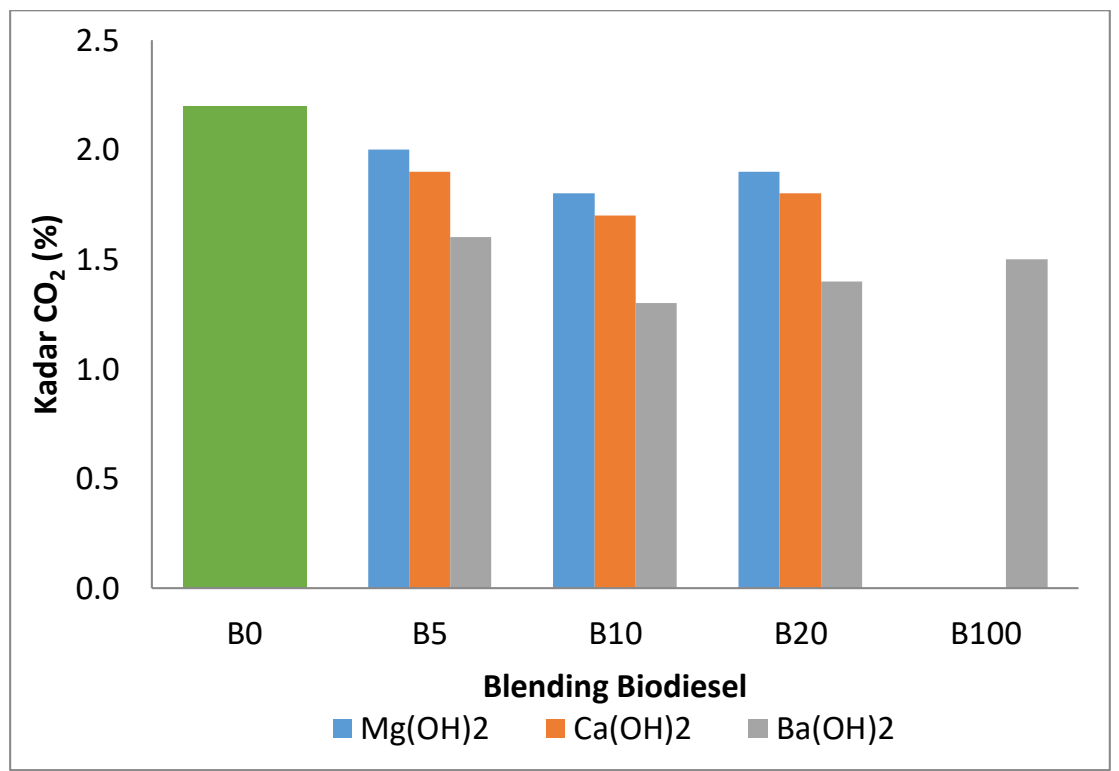

Graphic 3.8 The effect of diesel fuel blending to $\mathrm{CO}_{2}$ content

Graphic 3.7 and 3.8 explains that additional $\mathrm{Mg}(\mathrm{OH})_{2}, \mathrm{Ca}(\mathrm{OH})_{2}$ and $\mathrm{Ba}(\mathrm{OH})_{2}$ catalysts can decrease gas emission content of $\mathrm{CO}$ and $\mathrm{CO}_{2}$ as resulted from fuel combustion. The decrement of $\mathrm{CO}$ and $\mathrm{CO}_{2}$ for $\mathrm{Mg}(\mathrm{OH})_{2}, \mathrm{Ca}(\mathrm{OH})_{2}$ and $\mathrm{Ba}(\mathrm{OH})_{2}$ catalysts on biodiesel tends to decrease for around $10 \%$. It is where the highest decrement is on diesel fuel blended for $10 \%$ that the use of catalyst proves the decrement of exhaust emission gas. 
Declining exhaust emission gas, especially $\mathrm{CO}$ and $\mathrm{CO}_{2}$ shown by the increment of $\mathrm{O}_{2}$. It is as depicted by Graphic 3.9.

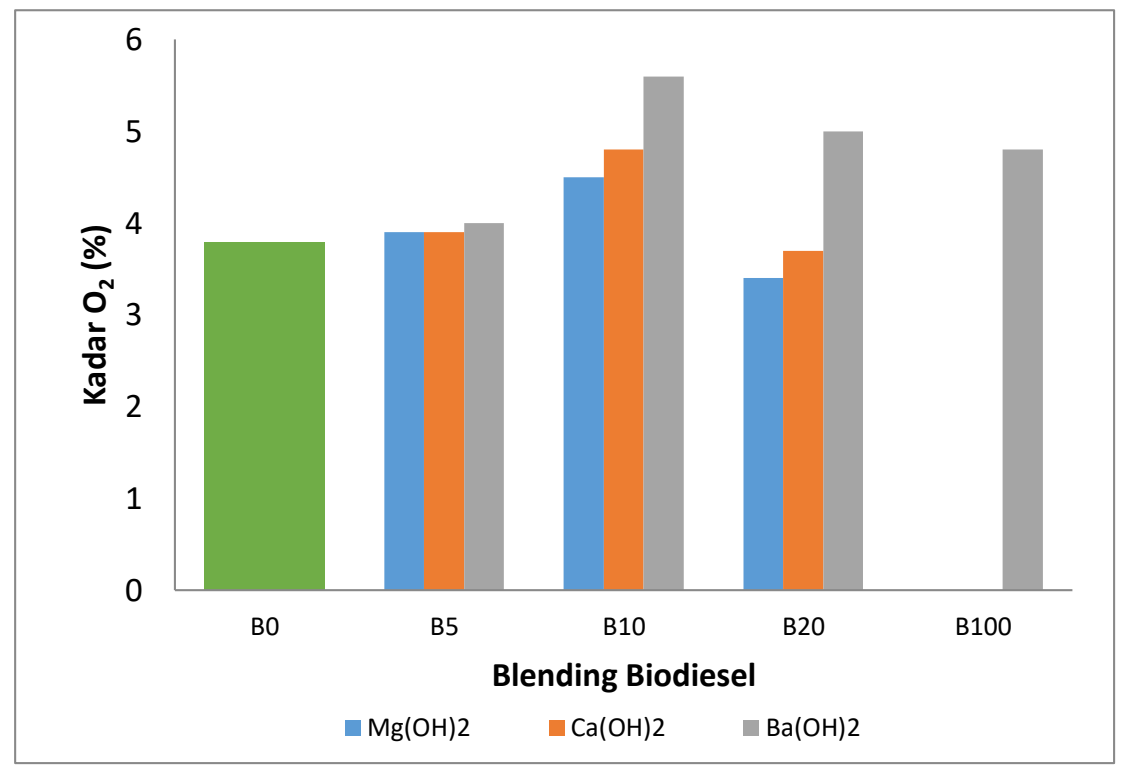

Graphic 3.9 The effect of diesel fuel blending to $\mathrm{O}_{2}$ content

Graphic 3.9 shows $\mathrm{O}_{2}$ increment as the decrement of exhaust emission gas. The increment of around $10 \%$ occurs on $10 \%$ biodiesel, especially on $\mathrm{Ba}(\mathrm{OH})_{2}$ catalyst. It is caused by $\mathrm{CO}$ and $\mathrm{CO}_{2}$ as the result of fuel combustion decreases that $\mathrm{O}_{2}$ increases.

\section{CONCLUSION}

$\mathrm{Mg}(\mathrm{OH})_{2}, \mathrm{Ca}(\mathrm{OH})_{2}$ and $\mathrm{Ba}(\mathrm{OH})_{2}$ catalysts can be alternative and additive catalysts on transesterification reaction. SFC increases with the increment of biodiesel amount added/blended to SFC diesel fuel as each catalyst increases from 0,0580 to 0,0706 than diesel fuel of 0,0543 . SFC needed by using $\mathrm{Ba}(\mathrm{OH})_{2}$ catalyst is more efficient when it is compared with other catalyst, it is 0,0640 while on $\mathrm{Mg}(\mathrm{OH})_{2}$ catalyst and $\mathrm{Ca}(\mathrm{OH})_{2}$ catalyst are respectively is 0,0706 and 0,0681 . Besides, in the bigger power of 5,861, $\mathrm{Ba}(\mathrm{OH})_{2}$ catalyst is able to ignite machine, while $\mathrm{Mg}(\mathrm{OH})_{2}$ and $\mathrm{Ca}(\mathrm{OH})_{2}$ catalysts cannot. $\mathrm{CO}$ and $\mathrm{CO}_{2}$ for $\mathrm{Mg}(\mathrm{OH})_{2}, \mathrm{Ca}(\mathrm{OH})_{2}$ and $\mathrm{Ba}(\mathrm{OH})_{2}$ catalysts on biodiesel tends to be $10 \%$ decreases. Therefore, $\mathrm{O}_{2} 10 \%$ increases in $10 \%$ biodiesel, especially on $\mathrm{Ba}(\mathrm{OH})_{2}$ catalyst.

\section{REFERENCES}

1. Knothe G. Biodiesel and renewable diesel: A comparison. Vol. 36, Progress in Energy and Combustion Science. 2010. p. 364-73.

2. Benjumea P, Agudelo J, Agudelo A. Basic properties of palm oil biodiesel-diesel blends. Fuel. 2008;87(10-11):2069-75.

3. Haseeb ASMA, Fazal MA, Jahirul MI, Masjuki HH. Compatibility of automotive materials in biodiesel: A review. Vol. 90, Fuel. 2011. p. 922-31.

4. Perry Alasti. Biodiesel Process [Internet]. United States; US20060074256A1, 2006. Available from:

https://patents.google.com/patent/US20060074256A1/en?q=Biodiesel\&q=Process\&i nventor $=$ Alasti\&oq $=$ Alasti+Biodiesel+Process

5. Jain S, Sharma MP. Prospects of biodiesel from Jatropha in India: A review. Vol. 14, Renewable and Sustainable Energy Reviews. 2010. p. 763-71.

6. Mariam S. Potensi Pengembangan Tanaman Jarak Pagar untuk Sumber Bahan Baku Biofuel. In Tanjungbalai; 2006. p. 29. Available from: https://anzdoc.com/potensipengembangan-tanaman-jarak-pagar-untuk-sumber-bahan-.html

7. Kulkarni MG, Dalai AK. Waste cooking oil - An economical source for biodiesel: A 
review. Vol. 45, Industrial and Engineering Chemistry Research. 2006. p. 2901-13.

8. Keskin A, Gürü M, Altiparmak D. Biodiesel production from tall oil with synthesized Mn and $\mathrm{Ni}$ based additives: Effects of the additives on fuel consumption and emissions. Fuel. 2007;86(7-8):1139-43.

9. Keskin A, Gürü M, Altiparmak D. Influence of tall oil biodiesel with $\mathrm{Mg}$ and Mo based fuel additives on diesel engine performance and emission. Bioresour Technol. 2008;99(14):6434-8.

10. Kannan GR, Karvembu R, Anand R. Effect of metal based additive on performance emission and combustion characteristics of diesel engine fuelled with biodiesel. Appl Energy. 2011;88(11):3694-703.

11. Gerpen J Van, Shanks B, Pruszko R, Clements D, Knothe G. Biodiesel Production Technology Biodiesel Production Technology. Vol. 87, Subcontractor Report. 2004.

12. Sharma YC, Singh B. Development of biodiesel: Current scenario. Vol. 13, Renewable and Sustainable Energy Reviews. 2009. p. 1646-51.

13. Tat ME, Van Gerpen JH. The specific gravity of biodiesel and its blends with diesel fuel. J Am Oil Chem Soc [Internet]. 2000;77(2):115-9. Available from: http://doi.wiley.com/10.1007/s11746-000-0019-3

14. Bhale PV, Deshpande N V., Thombre SB. Improving the low temperature properties of biodiesel fuel. Renew Energy. 2009;34(3):794-800.

15. Ramadhas AS, Jayaraj S, Muraleedharan C. Biodiesel production from high FFA rubber seed oil. Fuel. 2005;84(4):335-40.

16. Rashid U, Anwar F. Production of biodiesel through optimized alkaline-catalyzed transesterification of rapeseed oil. Fuel. 2008;87(3):265-73.

17. Alptekin E, Canakci M. Determination of the density and the viscosities of biodieseldiesel fuel blends. Renew Energy. 2008;33(12):2623-30.

18. Tesfa B, Mishra R, Gu F, Powles N. Prediction models for density and viscosity of biodiesel and their effects on fuel supply system in $\mathrm{Cl}$ engines. Renew Energy. 2010;35(12):2752-60.

19. Dorado MP, Ballesteros E, López FJ, Mittelbach M. Optimization of alkali-catalyzed transesterification of Brassica Carinata oil for biodiesel production. Energy and Fuels. 2004;18(1):77-83.

20. Levenspiel O. Chemical Reaction Engineering. John Wiley Sons, Newyork [Internet] 1999;38(11):4140-3. Available from: http://pubs.acs.org/doi/abs/10.1021/ie990488g

21. Liu X, He H, Wang Y, Zhu S, Piao X. Transesterification of soybean oil to biodiesel using $\mathrm{CaO}$ as a solid base catalyst. Fuel. 2008;87(2):216-21.

22. Koh MY, Ghazi TIM. A review of biodiesel production from Jatropha curcas L. oil. Renew Sustain Energy Rev [Internet]. 2011;15(5):2240-51. Available from: http://dx.doi.org/10.1016/j.rser.2011.02.013 